\title{
The Visionary of Leadership in Indonesian Navy as a Concept and Effective Strategy towards the World Class Navy
}

\author{
Sulistiyanto \\ Dinas Pendidikan angkatan laut (DISDIKAL) Gedung B3 Cilangkap Jakarta \\ Doctoral Program, Department of Human Resource Management, Jakarta State \\ University \\ Jl. Rawamangun Muka, RT.11/RW.14, Rawamangun, Jakarta Timur, 13220 \\ E-mail: sulis1061@yahoo.com
}

Nani Kusmiyati

Dinas Pendidikan angkatan laut (DISDIKAL) Gedung B3 Cilangkap Jakarta Doctoral Program, Department of Human Resource Management, Jakarta State University

Jl. Rawamangun Muka, RT.11/RW.14, Rawamangun, Jakarta Timur, 13220

E-mail: nani1navy@gmail.com

Hady Efendy (Corresponding Author)

Education Practice and Academic Consultant

E-mail: efendy_hady@yahoo.co.id

Received: August 3, 2017 Accepted: August 18, 2017 Online published: September 22, 2017 doi:10.5296/ijhrs.v7i4.11621 URL: https://doi.org/10.5296/ijhrs.v7i4.11621

\begin{abstract}
The era of globalization has given a tremendous impact on the nation development. Facing globalization era, the Indonesia Navy also experience the impact. Step taken by the Indonesian Navy is to change its vision to guard the archipelagic territory. To be a
\end{abstract}


world-class Navy is a challenge. The Indonesian Navy should have standardized main weapon system equivalent to other countries and leaders able to employ Human Resources as "human capital" in which a person with the skills and expertise competent to adapt to various conditions. Leadership has a decisive position within the organization. Leadership relevant to the changing times and for the quality improvement is a leadership with core work to focus on engineering the future challenges. It can be said that a visionary Navy leader is effectively able to transform rational changes in his organization.

Keywords: Human resource, leadership, navy, visionary, world class navy

\section{Introduction}

The era of globalization has given a tremendous impact on the nation development. The impact has changed into borderless world, and created rapid and dynamic science and technology into competition in various aspects of life. This condition leads to an understanding that "an organization able to survive is an organization capable of adapting to all changes and competition, and vice versa".

Facing globalization era, the Indonesian Navy also experience the impact. Step taken by the Indonesian Navy is to change its vision to guard the archipelagic territory. The current vision is "reliable, respected and world-class Navy".

To be a world-class Navy is a challenge. The Indonesian Navy should have standardized main weapon system equivalent to other countries and leaders able to employ Human Resources as "human capital" in which a person with the skills and expertise competent to adapt to various conditions.

Leadership has a decisive position within the organization. Effective leaders can their personnel toward a desired goal, on the contrary symbolic leaders have no leadership influence and can lead to poor organizational performance. Leadership relevant to the changing times and for the quality improvement is a leadership with core work to focus on engineering the future challenges.

\subsection{Management and Leadership}

The terms of management and leadership are often exchanged. It happens because management activities that include planning, leading, organizing and controlling, is considered no different from leadership activities. But John Kotter says that management is concerned with overcoming complexity, while leadership is concerned with overcoming change (Robbins, 2003). It can be reiterated that leadership is related to the vision of the future, while management is concerned with implementing the vision and strategy presented by leaders. The difference between the two terms is also raised by Robert House (Robbins, 2003). Mullins (2005) also pointed out that management deals with planning, organizing, directing, and controlling activities undertaken by subordinates.

Leadership is more emphasis on communication, motivate and encourage subordinate spirit to act optimally for a purpose. Hollingswoeth points out the fundamental differences between management and leadership (Mullins, 2005), namely: 
a. A manager performs administration, while a leader innovates.

b. A manager maintains what it is, while a leader builds what is needed.

c. A manager focuses on the system and structure, while a leader focuses on the subject.

d. A manager performs supervision, while leaders build trust.

e. A manager sees things in detail, whereas leaders see things in general.

f. A manager does everything right, while the leader chooses what should be done.

\subsection{Visionary Leadership}

There are some notions of visionary leadership. Seth Kahan (2002) explains that visionary leadership involves extraordinary ability to offer success and future glory. A visionary leader is able to anticipate events that may arise, manage the future and encourage others to act in the right ways. That means, visionary leaders are able to see the challenges and opportunities before they occur and then bring the organization to achieve its best goals.

Corinne McLaughlin (2001) defines visionary leaders as those able to build a "new dawn" with intuition and imagination, appreciation, and boldness. They present a challenge as an effort to give the best for the organization and make it as an inspiration to achieve organizational goals. They work with full power to achieve higher goals. They are social innovators, change agents, looking at things in a big picture and always thinking strategically.

Visionary leadership is a leadership pattern to give meaning to work and effort that needs for members of the organization by giving direction and meaning to work and effort based on clear vision (Kartanegara, Diana, 2003). Vision can be defined as everything to be achieved ideally from all activities. Vision is also as a mental picture of something to be achieved in the future.

Visionary leadership has distinctive characteristics that form attitude and behavior. According to Nasir (2012) visionary leadership is:

a. Having future insight: The visionary leader has a clear vision to achieve, so the organization able to flourish, in accordance with the vision he wants to achieve.

b. Dares to act in achieving goals, confident, and always be ready to take risks. The visionary leader also shows a careful, accurate calculation of the events he considers important.

c. Able to influence others to work hard to reach goals. The visionary leader is an exemplary leader, he wants the community around to imitate.

d. Able to formulate a clear vision, inspirational and manage the "dream" to be come true and has strong commitment.

e. Able to change vision into action, to formulate it into mission as orientation to step forward.

f. Holds to values he believes.

g. Builds effective relationships; in terms of motivating, making members more advanced, independent and high integrity.

h. Innovative and proactive: Always to observe the steps ahead and issues the latest issues about the organization. 
McLaughin (2001) defines characters of visionary leadership as:

a. To commits to values. They embody personal integrity and energetic, vitality and appetency.

b. To have a clear vision and able to make it into realize.

c. Respects good relationships manifested in caring to others, shows greater respect for others and carefully develop team spirit.

d. Dares to take innovative steps, to change the old paradigm.

A visionary leader should understand the concept of vision. Vision is thinking about organization future as a key that creates an advanced organizational culture toward global competition. He has all attitude and behavior to achieve the vision, sees far ahead and accustoms to face all challenges and risks. Among the main features of visionary leadership are:

a. Future-minded, acting as a motivator, best performance oriented, able to provide systematic direction.

b. Dare to reach goals, confident to face risks. At the same time, he also shows careful, accurate calculations.

c. Able to influence others to work hard to achieve goals, be a model that demonstrates values, provides positive feedback, and always appreciates accomplishments.

d. Being able to formulate a vision into action, inviting others to change and inspire others to work more creatively and harder.

e. Hold tightly to the values he believes. He has personality integrity, and radiating energy to always stand in line with his values as Mahatma Gandhi said: "I must be the first change I want to see in my world."

f. He cares to others, looks at other people as a valuable asset to be noticed, treats them well and 'warm' like a family.

g. He is innovative, proactive and productive in finding breakthroughs. He prefers to use 'win-win' than 'win-lose' approach.

Visionary leadership is aimed at giving meaning to work and effort that needs to be done in a team done based on clear vision (Kartanegara, Diana, 2003).

\subsection{Leadership Competencies}

To be a leader he must go through four levels (empirical existence, wide awareness, spirit, and existence). These levels are hierarchical, each higher level encompassing and giving directions of previous levels. Effective leaders will always try to develop themselves and move up to the hierarchy ladder. To climb the stages in the human potential ladder, a leader must have competence. Competence is a fundamental character that enables him to demonstrate effective performance in a job (Spencer and Spencer: 1993)

However, Burt (1992) states that visionary leader should have four key competencies, such as: 


\section{Macrothink}

International Journal of Human Resource Studies

ISSN 2162-3058

2017, Vol. 7, No. 4

a. Able to communicate effectively and produces "guidance, encouragement, and motivation" to others

b. Recognizes his environment and able to react skillfully to every opportunity and threat.

c. To have a very important role in the organization and successfully achieved the vision.

d. Able to manage resources to challenge any needs and changes.

Barbara Brown puts forward 10 competencies for visionary leaders, they are:

a. Visualizing; He has a clear picture of what to achieve and when to be achieved.

b. Futuristic Thinking; He thinks not only the business stands at the moment, but also it will be in the future.

c. Showing Foresight; $\mathrm{He}$ is a good planner and counts every resources.

d. Proactive Planning. He sets specific goals and strategies to achieve them as well to anticipate potential obstacles.

e. Creative Thinking; he would find alternatives ways and solution. He says "If it isn't broke, BREAK IT!"

f. Taking Risks. He dares to take risks and considers failure as an opportunity to bounce back higher.

g. Process alignment. He is able to quickly align his goals to organization goals.

h. Coalition building. He actively seeks opportunities to cooperate with various individuals, departments and classes.

i. Continuous Learning. He is able to regularly take part in training and other types of development, he pursues opportunities to work together and take part in projects that can broaden knowledge, challenge thinking and develop imagination.

j. Embracing Change. He recognizes that change is an important part of growth and development. He actively investigates the ways and benefits the change.

According to Hitt (1993) there are 25 important competencies in a leader that encapsulate in five dimensions, as in Table 1.

Table 1. Leadership Competences

\begin{tabular}{|c|c|}
\hline Dimension of Leadership & Leadership Competences \\
\hline Reason & $\begin{array}{ll}\text { - } & \text { Conceptual skills } \\
\text { - } & \text { Logical thinking } \\
\text { - } & \text { Creative thinking } \\
\text { - } & \text { Holistic thinking } \\
\text { - } & \text { Communication }\end{array}$ \\
\hline Sources of Power & $\begin{array}{ll}\text { - } & \text { Staff } \\
\text { - } & \text { Information } \\
\text { - } & \text { Network }\end{array}$ \\
\hline Knowledge & $\begin{array}{ll}\text { - } & \text { Knowing oneself } \\
\text { - } & \text { Knowing the job } \\
\end{array}$ \\
\hline
\end{tabular}




\begin{tabular}{|c|l|}
\hline & $\begin{array}{l}\text { - Knowing the organization } \\
\end{array}$ \\
- Knowing the business is in \\
- Knowing the world
\end{tabular}

\section{a) Reason}

Human thought fills with concepts and facts. Reason can consolidate different facts and concepts into a meaningful object. Reason asks, tests, and answers facts. The manifestation of reasoning includes: 1) conceptual skills, i.e. abstraction and generalization, 2) logical thinking, i.e. the ability to apply a systematic approach to problem solving, 3) creative thinking, i.e. the ability to bring ideas into reality, 4) holistic thinking, ability to lift the total situation, and 5) communication, i.e. the ability to dialogue, to seek the truth accepted by both parties in a disagreement.

\section{b) Sources of Power}

Power is important in effective leadership. The main sources of power: 1) the staff, the team who are prepared, willing to work, and have the ability to do the job, 2) the information, the knowledge needed to do Work, and 3) networks, i.e. personal contacts, with whom ideas, information and resources can be shared. Handy (1996) mentions three attributes that the leader needs to gain power from his followers: having a strong self-confidence, having passion for work, and loving others with a courage to walk in solitude. A Leader must also gains credibility and trust from their subordinates (Chandra: 1997; Pradiansyah: 1997). In order to gain credibility, a leader should be honest, inspirational, and capable.

\section{c) Knowledge}

An effective leader has knowledge. Although not all information can be mastered, they must be able to filter out important information. For effective leaders, there are five characteristics of knowledge, including: 1) knowing yourself. Knowing the strengths and weaknesses of oneself and actively seeking feedback for growth, 2) knowing the job; understand the job requirements and how the job contributes to the organization, 3) know the organization; 
understand organizational culture and how to do things effectively and efficiently, 4) knowing his business entered; understanding the client needs and what is valuable to them, and 5) knowing the world; understand the community in the world and how small communities relate to the great.

\section{d) Core leadership function}

An effective leader is able to elevate the values of his followers by encouraging his followers to climb the hierarchy to the point of "new value". He carries out six core functions, namely: 1) judging; He knows the values of the organization and is able to translate those in practice, 2) Creating. Having a clear mental picture of the desired future of the organization, 3) Guiding; Help others develop the knowledge and skills needed to achieve the vision, 4) empowering. Helping others to achieve the mission, 5) Building a team. Build coalitions with people to achieve the vision, and 6) promoting quality; Achieve reputation to meet or exceed customer expectations.

\section{e) Character}

A good leader should have the following 6 characteristics: 1) identity. Knowing who he is and possessing wholeness and integration, 2) independence. Being a self-directed person, 3) authenticity. Demonstrate the true identity, maintaining the appropriateness between the value of oneself and the value that is beyond it, 4) responsible for the actions and decisions made, 5) the courage to keep going despite the obstacles, and 6) the integrity; Guided by a number of moral principles and recognized by others as people of integrity.

In addition to having the above competencies, effective leaders for future organizations also possess a number of specialized skills. White, et al. (1997) mentioned the special skills owned, includes: difficult learning, maximizing energy, resonant simplicity, multiple focus, and mastering inner sense.

Difficult learning; In organizational learning, organizational leaders are able to encourage all members of the organization to identify what they do not know and all the problems that have not yet been found how to solve them. Maximum energy; the future leader is able to maximize power to make quality business decisions, has a strong impetus to get out of the present status quo. Resonant simplicity; the leader of the future organization should have the thinking skills and work simply to support the communication process. Multiple focuses; Future organizational leaders are able to unite the thinking and acting of different members of the organization regarding strategic plans and activities, through persuasive methods and advocacy. Mastering inner sense; under any circumstances, he uses his thought to make quick decision and has inner sense.

\section{Discussion}

\subsection{Characteristics of Effective Leaders}

It is believed that organization faces changes that will affect the life of the organization. Whatever style of leadership to choose, in such conditions the organization needs effective leadership so he can lead the organization to achieve its goals. 


\section{Macrothink}

International Journal of Human Resource Studies

ISSN 2162-3058

2017, Vol. 7, No. 4

Leadership effectiveness is difficult to measure because of its multidimensional and qualitative nature. Tannenbaum and Schmidt (1958) in Sofiati (1995) conducted a study on 161 managers as participants of the Management Education Program at Harvard Business School to identify the characteristics needed to be effective leaders. The results shows that leader effective characteristics are: 1) developing, training and protecting subordinates, 2) communicating effectively with subordinates, 3) informing subordinates about what the company expects from them, 4) setting high standards of work, 5) recognizing subordinates and their skills , 6) giving role to subordinates in the decision making process, 7) always informing subordinates about the condition of the company, 8) being aware of the company's moral condition and always trying to increase it, 9) willing to make changes in doing something, and 10) appreciate the achievement of subordinates.

Effective leaders can be achieved when he establishes good communication with subordinates and work to achieve organizational goals. The problem is, who deserves to give an assessment of the effectiveness of leadership? A leader is a center of organization, the assessment of a leader should be done by the people around him who interact and run organizational activities together. In this case, it is the subordinates who know the wheel of leadership.

\subsection{Strategy Improving Leadership Effectiveness}

Above describes the leadership characteristics and competencies possessed by leaders to achieve effectiveness. Then the question arises, what if a leadership cannot achieve effectiveness? Tannenbaum and Schmidt (1958) in Sofiati (1995) mentioned to overcome the possibility of ineffectiveness, organizations need to create leadership substitutes, leadership neutralizers, and leadership enhancers.

The essence of these three strategies is the creation of certain characteristics in the organization. Thus the task of a leader can be substituted. The creation of certain characteristics aimed at assisting the inner leader's work increase influence to subordinates, called leadership enhancers. The creation of certain characteristics aimed at neutralizing and reducing the influence of superiors on subordinates, called leadership neutralizers. To improve leadership effectiveness, organizations can adopt a strategy called "Creative Strategies for Improving Leadership Effectiveness" (see Table 2).

Table 2. Creative Strategies for Improving Leadership Effectiveness

\begin{tabular}{|l|ll|}
\hline $\begin{array}{l}\text { Creating Substitutes for leaders } \\
\text { directiveness and supportiveness }\end{array}$ & $\begin{array}{l}\text { Creating enhancers for leaders } \\
\text { directiveness and supportiveness }\end{array}$ \\
\hline Develop collegial systems of guidance: & $\begin{array}{l}\text { Increase subordinates perceptions of } \\
\text { leader's influence/expertise: }\end{array}$ \\
\hline $\begin{array}{l}\text { Peer appraisals to increase } \\
\text { acceptability of feedback by } \\
\text { subordinates }\end{array}$ & Provide visible champion of leader & \\
\hline - $\begin{array}{l}\text { Quality circles to increase workers } \\
\text { control over production quality }\end{array}$ & $\bullet$ Give leader important organizational & \\
\hline
\end{tabular}




\begin{tabular}{|c|c|}
\hline & responsibilities \\
\hline $\begin{array}{l}\text { - Peer support networks; mentor } \\
\text { systems }\end{array}$ & $\begin{array}{l}\text { - Build leader's image through in house } \\
\text { publications and other means }\end{array}$ \\
\hline $\begin{array}{l}\text { Improve performance oriented } \\
\text { organization: }\end{array}$ & Build organizational climate \\
\hline $\begin{array}{l}\text { Automatic organization reward } \\
\text { system (such as commissions or } \\
\text { gainsharing) }\end{array}$ & $\begin{array}{l}\text { - Reward small wins to increase } \\
\text { subordinates confidence }\end{array}$ \\
\hline - Group MBO program & $\begin{array}{l}\text { Emphasize ceremony and myth to } \\
\text { encourage cohesiveness and high } \\
\text { performance norms }\end{array}$ \\
\hline $\begin{array}{l}\text { - Company mission statements and } \\
\text { codes of conduct }\end{array}$ & $\begin{array}{l}\text { Increase subordinates dependences on } \\
\text { leader: }\end{array}$ \\
\hline $\begin{array}{l}\text { Increase administrative } \quad \text { staff } \\
\text { availability: }\end{array}$ & - Create crises requiring immediate action \\
\hline - Specialized training personnel & $\begin{array}{l}\text { - Increase leader centrality in providing } \\
\text { information }\end{array}$ \\
\hline $\begin{array}{l}\text { - Troubleshooters for human relations } \\
\text { problem }\end{array}$ & - Eliminate one-over-one approvals \\
\hline $\begin{array}{l}\text { Technical advisors to assist } \\
\text { production operators }\end{array}$ & Increase leader's position power: \\
\hline $\begin{array}{l}\text { Increase professionalism } \\
\text { subordinates: }\end{array}$ & - Change title to increase status \\
\hline $\begin{array}{l}\text { Staffing based on employee } \\
\text { professionalism }\end{array}$ & - Increase reward power \\
\hline $\begin{array}{l}\text { Development plans to increase } \\
\text { employee ability and experience }\end{array}$ & - Eliminate resource base \\
\hline $\begin{array}{l}\text { - } \begin{array}{l}\text { Encourage active participation in } \\
\text { professional associations. }\end{array}\end{array}$ & $\begin{array}{l}\text { Create cohesive work groups with high } \\
\text { performance norms: }\end{array}$ \\
\hline Redesign jobs to increase: & $\begin{array}{l}\text { - Provide physical setting conductive to } \\
\text { teamwork }\end{array}$ \\
\hline - Performance feedback from the task & $\begin{array}{l}\text { - Encourage subordinates participation in } \\
\text { group problem solving }\end{array}$ \\
\hline - Ideological importance of the jobs & - Increases groups status \\
\hline
\end{tabular}




\begin{tabular}{|l|l|}
\hline $\begin{array}{l}\text { Start team-building activities to } \\
\text { develop group self-management skills } \\
\text { such as: }\end{array}$ & $\bullet$ Create intergroup competition \\
\hline $\begin{array}{l}\text { Solving work-related problems on } \\
\text { their own }\end{array}$ & \\
\hline - $\quad \begin{array}{l}\text { Resolving interpersonal conflicts } \\
\text { among member }\end{array}$ & \\
\hline - $\begin{array}{l}\text { Providing interpersonal support to } \\
\text { members }\end{array}$ & \\
\hline
\end{tabular}

Source. Sofiati, Evi. (1995), Mencari Pola Kepemimpinan yang Efektif, Usahawan. Januari page 20-25.

\subsection{Leadership Effect on Organizational Change}

In an organization, "leadership" is one of the main factors supporting the organization's success in achieving its goals. Gibson, Lancevich, and Donnelly (1996: 6) define the organization as "a container that enables society to achieve results previously unattainable by individuals individually".

There are three prominent theories (Sunindhia and Ninik Widiyanti, 1988: 18), namely: (1) Genetie Theory. It is summed up in "leaders are born and not made"; a leader will exist because he was born with a leader's talent. It means that fate has established him to be a leader; (2) Social Theory. Socialists say: "Leaders are made and not born". This theory argue that everyone can become a leader if he has education and opportunity; (3) Ecological Theory. This theory is a refinement of both genetic theory and social theory. This theory argue that one can be a good leader if at birth he has leadership talents, and it is developed through education and experience, allowing him to further develop the talents.

Ecological theory echoes the positive aspects of both genetic theory and social theory and is arguably the best theory of leadership theories. However, a much deeper inquiry is needed to say with certainty the factors that cause a person to arise as a good leader.

The influence of leadership on change is expressed by Hersey (2000: 491) that influential leaders, do not carry out changes in the void conditions, but changes are perfected carefully through the creation of various parts. Hersey further explained that positive impacts can be proposed for a pre-determined change of purpose. Yulk (2002: 296) explains that leading change is one of the most important and difficult leadership responsibilities, effective leadership is needed to revitalize the organization and facilitate adaptation to changing organizational environments.

Richard L. Daff suggests the concept of leadership is an influence of the relationship between leader and follower who intend to change and concrete results that reflect common goals. Based on these definitions, there are seven essential elements in leadership, (1) leader, (2) influences, (3) Follower, (4) intention, (5) shared purpose, (6) change, (7) personal 


\section{Macrothink}

International Journal of Human Resource Studies

ISSN 2162-3058

2017, Vol. 7, No. 4

responsibility. Influence is a reciprocal relationship between leaders and followers as a result of a common goal. Based on the view of Daff, the influence is not associated with elements of power or coercion by the leader against subordinates. While the element of change is the result of leadership and followers are both creating change, not maintaining the status quo? In other words, change is a shared purpose. In seven elements of leadership that Daff points out, there is significant point, there is no real difference in giving influence and responsibility to achieve change between leaders and followers.

Burt Nanus (1999: 18) finds a special model used to understand the role of non-profit organization leaders embodied in the activities, namely:

a. Inside the organization, the leadership roles interact with staff and volunteers to inspire, encourage, mobilize and empower them.

b. Outside organizations, leadership roles seek help, support from donors, potential partners with business leaders outside the organization.

c. During the operation period, leaders focus on quality and service, on organizational structure, information systems and other aspects.

d. On future possibilities, leaders anticipate trends and develop future direction of the organization. These four things consist of six roles which are the activities of the leader in carrying out his leadership and by Burt as in figure 1.

Outer Organization

\begin{tabular}{c|cc} 
& Operation Period & $\begin{array}{c}\text { Giving vision and } \\
\text { Strategy }\end{array}$ \\
\cline { 2 - 3 } Operation Period & Poach & Change Agent \\
In Organization
\end{tabular}

Figure 1. Non-Profit organization leadership

Source: Burt Nanus. Leaders Who Make a Difference for Meeting

The non Profit Challenge (1999: 18)

1) Roles 1 and 2: Leaders as visionaries and strategies are responsible for moving the organization in the right direction. Then they establish, spread and develop the vision clearly and show new ways in the future. They provide inspiration to their members as well as designing strategies to achieve the vision and mission of the organization. 
2) Roles 3 and 4: Leaders as politicians and campaigners serve as advisors, spokespersons and as negotiators to their subordinates, also build relationships using super-networked sources of information.

3) Role 5: Leader as a coach has embedded the nature of team building and fostering people in the organization. In addition, leaders also play a role to build trust that become the organization's grip and inspiration of each individual.

4) Role 6: Leaders as change agents have a major influence in decision-making for change and introducing new programs, creating collaborative strategies with the public. Sometimes an organizational restructuring and innovation.

As agents of change, leaders are individuals who are responsible for altering the systems and behavior of organization. Kurt Lewin and Schein argue that successful change in the organization should follow four steps, (1) desire of change, before change occurs every individual must perceive a need in the form of deficiencies or dissatisfaction and desires (2) unfreezing, which involves encouraging, persuading through approaches by reducing threats and resistances so that each individual is ready to change, (3) changing which involves giving change to each individual through learning new in their attitude by giving new information, new behavioral models, and new ways of seeing things and (4) refreezing new changes to make it permanent. In addition, Peter Hernon, Ronald R (2003: 131) states that in order to assess the leadership of academic library organizations, leaders should (1) have vision and goal strategy for library organizations, (2) serve people who contribute to the campus, (3) and be creative, (4) builds their members, maintain morale and inspire.

On the other hand, it is necessary to get a thorough understanding, especially in the leadership model based on the behavior and skill of a person who mingle and then forms a different style of leadership. Some of the models that follow this approach, among others, are as follows. Continuum model leadership (Autocratic-Democratic). Tannenbaun and Schmidt in Hersey and Blanchard (1996) argue that leaders influence followers in several ways, from a way that accentuates the extreme side so-called autocratic behavior to a way that accentuates the other extremes so-called democratic behavior. Autocratic behavior, generally considered negative, where the source of power or authority comes from the influence of leadership. So authority is in the hands of leaders, because the concentration of power and decision-making is on him and holds full responsibility, while his subordinates are affected through threats and punishment. In addition to being negative, this leadership style has benefits, among others, quick decision making, can give satisfaction to the leadership and provide a sense of security and regularity for subordinates. In addition, the main orientation of this autocratic behavior is on duty.

Democratic behavior; this leadership behavior obtains a source of power or authority that begins with subordinates. This happens when a subordinate is properly motivated and the leader in carrying out his leadership seeks to prioritize teamwork and cooperation to achieve goals, where the leader is happy to accept suggestions, opinions and even criticism from his subordinates. The policy here is open to discussion and group decisions. Tannenbaun and Schmidt in Hersey and Blanchard (1996) categorize it into seven leadership behavior trends. 


\section{NIMacrothink}

International Journal of Human Resource Studies

ISSN 2162-3058

2017, Vol. 7, No. 4

These seven behaviors are not absolute but will have the tendency of leadership behavior to follow a continuum line from the task-oriented autocratic side to the relationship-oriented democratic side, as shown in Figure 2.

Ohio Leadership Model. In his research, Ohio University gave birth to a two-factor theory of leadership style, namely initiation and consideration structure (Hersey and Blanchard, 1996). Initiation structure refers to the leader's behavior in describing the relationship between himself and the working group members in an effort to shape organizational patterns, communication channels, and well-defined methods or procedures. As for consideration refers to behaviors that show friendship, mutual trust, respect and warmth in relationships between leaders and staff members (subordinates). As an example of a consideration factor such as a leader providing time to listen to group members, leaders are willing to make changes, and leaders are friendly and approachable. As an example for initiation structure factors such as leaders assigning specific tasks to group members, leaders ask group members to comply with standard rules and rules, and leaders tell group members what they expect from them. The two factors in the Ohio leadership model in its implementation refer to four quadrants, namely: (a) low leadership models of considers and their structure of initiation, (b) high leadership models of consideration or initiation structure, (c) high leadership model but low Its structure of initiation, and (d) a low-conscious leadership model but a high initiation structure, as shown in Figure 3.

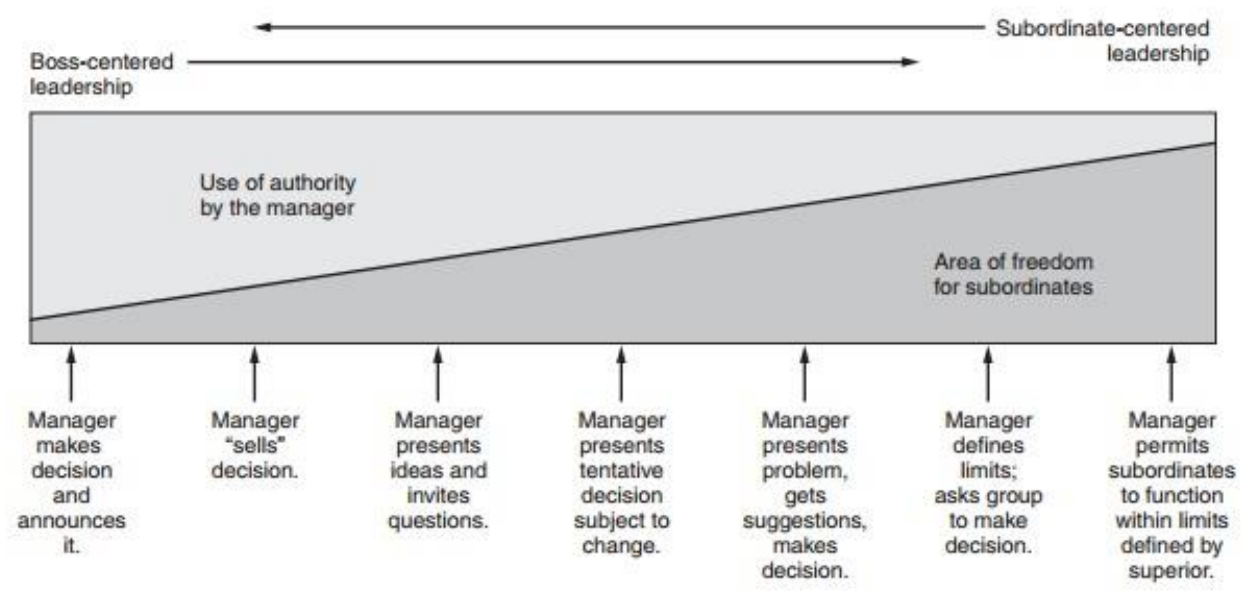

Figure 2. Continuum line from autocracy oriented on duty to democracy oriented on relation. (Tannenbaun and Schmidt in Hersey and Blanchard (1996)) 


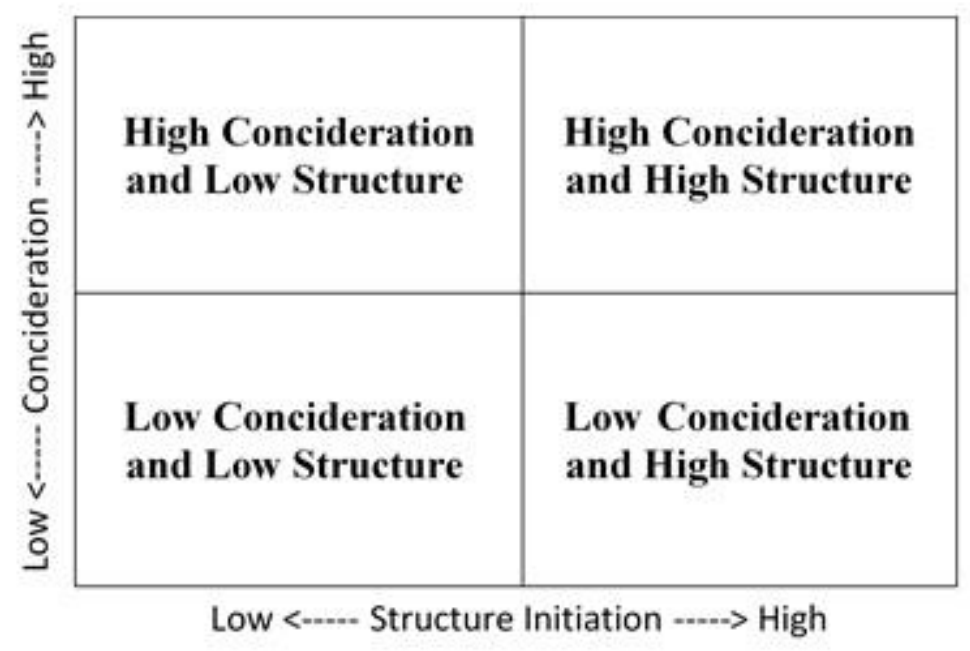

Figure 3. Initiation and considering structure (Hersey dan Blanchard, 1996).

\subsection{Visionary Leadership of the Indonesian Navy towards World Class Navy}

Organizational development is influenced by commitment to the values. The leader is the most skilled in promoting and protecting those values. Successful leaders are able to personify their values and live the values in their organization. In the Indonesian Navy, the existence of leadership is needed to provide a change to a better direction, because its position is in a very decisive position to be a role model for members.

In the Indonesian Navy, a leader has characteristics, as follows:

a. Religious. Always aware of himself that everything comes from the Creator, will always do the best for his people because God the Creator who always knows what we do. Therefore, the leadership of the Navy comes from the values of "God" which includes: honest, future-oriented, responsibility, cooperation, fair, discipline and care.

b. Visionary. Always to thinks and does for the achievements and goals of organization. Visionary thinking means reaching forward and always making predictions of circumstances, calculations of risks and alternative actions. At a higher level such as the Operational Units always make the Operation Plan coupled with the Action Plan facing contingency.

c. Technocracy. Always to thinks rationally in the sense of putting forward the ideas and concepts of renewal, not power and coercion. As a technocrat in making decisions. He conveys rational concepts and ideas to his subordinates to be processed from different perspectives. Such leadership is called intellectual leadership.

d. Sosiocracy. The Navy is an "arm of state" in the regions with heterogeneous socio-cultural diversity, they are as a bridge to channel the people aspirations to the center and able to convey the policies of state governance to the regions in nation-building. Such leadership is called the rationalist sociocracy.

e. International thinking. Navy as a tool of state diplomacy, should guarantee the credibility of the country in the international world. A Navy leader should be broad-minded in the 
field of international relations, international law and capable as a negotiator in terms of disputes with other countries, especially in marine disputes.

Based on these traits, the Indonesian Navy has made changes to the leadership pattern that places visionaries as part of the leadership of the Indonesian Navy in relation to the demands of the current era of making the world class navy.

\section{Conclusion}

Visionary leadership is the ability of leaders in creating, formulating, communicating or socializing, transforming and implementing ideal thoughts as a result of social interaction among members of the organization and stakeholders who believe the ideals of the future organization achieved or realized through the commitment of all personnel. Visionary leadership is a figure capable of connecting the vision of the people. Leads through persuasive ways and can influence them to change their perceptions of what is important to them and to the organization.

In addition, a visionary leader has the expertise and authority to control and establish communicative relationships with subordinates and assure subordinates that their interests are part of the organization's vision. Showed a great initiative and willingness to realize the vision and is driven by an orientation to achievement and have high levels of ambition, energy, perseverance and proactive attitude and use the power to be something that can be created and distributed to subordinates without diminishing their own power.

The visionary leaders are individuals capable of: (a) building up the confidence of their subordinates, (b) communicating a belief in their ability to succeed, (c) granting or delegating authority; (d) creating challenges; (e) developing accountability in the organizational environment; (f) receiving feedback; (g) giving rewards of the achievement. It can be said that a visionary Navy leader is effectively able to transform rational changes in his organization.

\section{References}

Burt, N. (1999). Leaders Who Make a Difference for Meeting the Non Profit Challenge.

Gary, Y. (2008). Leadership. Albany. New York.

Handy, C. (1996). The New Language of Organizing and Its Implication or Leaders, Dalam Frances Haessel bein, Marshal Goldsmith, Richard Beckard (Eds). The Leader of the Future: New Vision, Strategies and Practices for the Next Era. San Francisco: Jossey-Bass Publisher

Hersey, P., Kenneth, H. B., \& Dewey, E. J. (1996). Management of Organizational Behavior: Utility Human Resources, New Jersey: Prentice Hall.

Hitt, W. D. (1993). The Model Leader: A Fully Functioning Person. Leadership \& Development Journal, 14(7), 4-11. https://doi.org/10.1108/01437739310046976

John, M. I. (2009). Organisation Behavior Structure and Processes, McGraw-Hill New York Amerika. 


\section{Macrothink}

International Journal of Human Resource Studies

ISSN 2162-3058 2017, Vol. 7, No. 4

Kartanegara, D. (2003). Strategi Membangun Eksekutif, http://www.pln.co.id/fokus/ArtikelTunggal.asp?artikelID=268.

Lussier, R. N., \& Christopher, F. A. (2010). Leadership, Theory, Application, and Skill Development, (Mason: Cengage Learning, Fourth Edition).

Richard, L. (2008). Daft with the Assistance of Patricia G. Lane. Management. Eighth Edition Thomson South Western, USA.

Sofiati, E. (1995). Mencari Pola Kepemimpinan yang Efektif. Usahawan, Januari, hal. 20-25.

Spencer, L. M., \& Spencer, S. M. (1993). Competence at Work: Models for Superior Performance. John Wiley \& son, Inc.

Stephen, R., \& Timothy, J. (2011). Organization Behavior: 15 edition, Pearson. New Jersey.

\section{Copyright Disclaimer}

Copyright for this article is retained by the author(s), with first publication rights granted to the journal.

This is an open-access article distributed under the terms and conditions of the Creative Commons Attribution license (http://creativecommons.org/licenses/by/4.0/). 